\title{
Mapping of the proinflammatory domains of MspTL of Treponema lecithinolyticum
}

\author{
Correspondence \\ Bong-Kyu Choi \\ bongchoi@snu.ac.kr
}

Received 1 February 2007

Revised 3 April 2007

Accepted 1 May 2007

\section{Hye-Kyoung Jun, ${ }^{1}$ Hae-Ri Lee, ${ }^{1}$ Sung-Hoon Lee ${ }^{1}$ and Bong-Kyu Choi ${ }^{1,2}$}

\author{
${ }^{1}$ Department of Oral Microbiology and Immunology, School of Dentistry, Seoul National University, \\ Seoul 110-749, Republic of Korea \\ ${ }^{2}$ Dental Research Institute, School of Dentistry, Seoul National University, Seoul 110-749, \\ Republic of Korea
}

\begin{abstract}
The major surface protein (MspTL) of Treponema lecithinolyticum, associated with periodontitis and endodontic infections, has been reported to induce proinflammatory mediators such as intercellular adhesion molecule (ICAM)-1, and interleukin (IL)-1 $\beta, \mathrm{IL}-6$ and IL-8. The purpose of this study was to examine the role of MspTL in cell adhesion/migration and to identify its proinflammatory domains. Using the human monocytic cell line THP-1 and human dermal microvascular endothelial cells (HMEC-1), it was demonstrated that MspTL increased adhesion of monocytes to endothelial cells and transendothelial migration. To analyse the proinflammatory domains of the protein, four gene constructs covering different regions of MspTL were designed and expressed in Escherichia coli using the expression vector pQE-30. Histidine-tagged recombinant proteins were purified using Ni-NTA agarose and polymyxin B agarose to remove LPS contamination. Recombinant truncated polypeptides were assessed for the ability to induce ICAM-1 and proinflammatory factors in THP-1 cells by real-time RT-PCR and ELISA. Of the four polypeptides, the one spanning the $\mathrm{N}$-terminal 86 amino acids significantly induced ICAM-1, IL-1 $\beta$, IL-6, IL-8, tumour necrosis factor- $\alpha$ (TNF- $\alpha$ ), cyclooxygenase (COX)-2, and prostaglandin $E_{2}\left(P G E_{2}\right)$. The results indicate that MspTL may induce cell adhesion and inflammation via its $\mathrm{N}$-terminal region.
\end{abstract}

\section{INTRODUCTION}

Oral spirochaetes are associated with periodontal diseases and endodontic infections. They include enormously diverse Treponema species (Choi et al., 1994; Dewhirst et al., 2000). Treponema lecithinolyticum is a small saccharolytic spirochaete with phospholipase A and C activities (Wyss et al., 1999), and belongs to the phylogenetic group IV oral Treponema that is frequently found in periodontitis (Choi et al., 1994; Moter et al., 2006; Wyss et al., 1999). Recently, these organisms were detected in infected root canals associated with either asymptomatic or symptomatic apical periodontitis (Siqueira \& Rocas, 2003). With most oral treponemes, the proportion of subjects positive for certain species or phylotypes was higher in subjects with chronic and aggressive periodontitis than in the periodontitis resistant subjects (Moter et al., 2006). This difference was pronounced for treponemes of

Abbreviations: COX-2, cyclooxygenase-2; GAPDH, glyceraldehyde-3phosphate dehydrogenase; GCF, gingival crevicular fluid; HMEC-1, human dermal microvascular endothelial cells; ICAM-1, intercellular adhesion molecule-1; IL, interleukin; MMP, matrix metalloproteinase; $\mathrm{PDL}$, periodontal ligament; $\mathrm{PGE}_{2}$, prostaglandin $\mathrm{E}_{2} ; \mathrm{PP}$, polypeptide; TNF- $\alpha$, tumour necrosis factor- $\alpha$. the phylogenetic groups II and IV, and for Treponema socranskii and T. lecithinolyticum. T. lecithinolyticum has been reported to activate matrix metalloproteinase-2 (MMP-2) in human gingival fibroblasts and periodontal ligament (PDL) cells (Choi et al., 2001a), and to induce osteoclast differentiation by a prostaglandin $\mathrm{E}_{2}\left(\mathrm{PGE}_{2}\right)$ dependent mechanism (Choi et al., 2001b). The bacterium possesses the prcA-prtP gene, whose product exhibits chymotrypsin-like protease activity (Correia et al., 2003).

Bacterial surface proteins promote diverse activities, including adhesion, cytotoxicity, antigenicity and host cell stimulation. Recently we reported that the major surface protein (MspTL) of $T$. lecithinolyticum induced proinflammatory factors in host cells (Lee et al., 2005). MspTL (590 amino acids, including the signal peptide of 19 amino acids) is homologous to the Treponema maltophilum major surface protein, MspA, with $53 \%$ identity and 59\% similarity. These homologous proteins stimulate the expression of interleukin (IL)-1, IL-6 and IL-8 and intercellular adhesion molecule (ICAM)-1 in THP-1 cells, a monocytic cell line, and primary cultured PDL cells. Identification of the functional regions of bacterial surface proteins will improve our understanding of bacteria-host interactions and may help diverse eradication strategies. 
The purpose of this study was to examine the role of MspTL in cell adhesion/migration and to identify its proinflammatory regions using truncated recombinant MspTL polypeptides.

\section{METHODS}

\section{Cloning of MspTL gene fragments and purification of truncated} MspTL polypeptides. MspTL gene fragments were amplified from genomic DNA of T. lecithinolyticum (ATCC 700332) by PCR and cloned in Escherichia coli using the expression vector pQE-30 as described previously (Lee et al., 2005). Purification of the recombinant proteins with Ni-NTA agarose and decontamination of endotoxin using polymyxin B agarose were also performed as described previously (Lee et al., 2005). The protein concentration was determined by bicinchoninic acid protein assay. The primers used for PCR to amplify MspTL and MspTL gene fragments were as follows: 5' -AACTGGATCCATGAACCTTCCGCCGAAGC-3' and 5' CCCGGAGCTCTTACAGAGCGATTTTCGCCTT-3' for the MspTL gene; $5^{\prime}$-AACTGGATCCATGAACCTTCCGCCGAAGC-3' and $5^{\prime}$ CCCGGAGCTCTTAATCGTCGTCTATTTTGGT-3' for the gene of polypeptide 1 (PP1) (1-86 aa positions); 5'-AACTGGATCCATGAACGTTAATTTGCTTACC-3' and $5^{\prime}$-CCCGGAGCTCTTACAGAGCGATTTTCGCCTT-3' for the gene of PP2 (75-571 aa positions); 5'-AACTGGATCCATGCTGGGTTATGAACAAAAA-3' and $5^{\prime}$-CCCGGAGCTCTTACTTTACGAGTTCGCCGGAATA-3' for the gene of PP3 (167-421 aa positions); 5'-AACTGGATCCATGAAACTGCTTCCCGGTGTT-3' and 5'-CCCGGAGCTCTTACAGAGCGATTTTCGCCTT-3' for the gene of PP4 (385-571 aa positions). The underlined sequences are the introduced recognition sites for BamHI (GGATCC) and SacI (GAGCTC). Four nucleotides were added to $5^{\prime}$ ends of these restriction sites. The mock extract was prepared from E. coli transformed with PQE-30 without the insert DNA, using the same chemicals that were used for recombinant MspTL polypeptides.

SDS-PAGE. Purified recombinant polypeptides were separated by a standard SDS-PAGE system (10\% gel) and visualized by staining with $0.1 \%$ Coomassie blue R-250.

Cell-binding assay. The effect of MspTL on cell binding was analysed using the human monocytic cell line THP-1 and human dermal microvascular endothelial cells (HMEC-1), which were purchased from the American Type Culture Collection. Binding was assessed as described by Al-Numani et al. (2003). THP-1 cells were cultured in RPMI 1640 medium (Gibco-BRL) with $10 \%$ FBS (fetal bovine serum) overnight and stimulated with $10 \mu \mathrm{g}$ MspTL $\mathrm{ml}^{-1}$ for $12 \mathrm{~h}$ in serum-free medium. In parallel, HMEC-1 cells were cultured in MCDB131 medium (Gibco-BRL) supplemented with $15 \%$ FBS, $1 \%$ antibiotics $\left(50 \mathrm{U}\right.$ penicillin $\mathrm{ml}^{-1}$ and $50 \mu \mathrm{g}$ streptomycin sulphate $\mathrm{ml}^{-1}$ ), $0.1 \mu \mathrm{g}$ hydrocortisone $\mathrm{ml}^{-1}$ (SigmaAldrich) and $0.1 \mu \mathrm{g}$ epidermal growth factor $\mathrm{ml}^{-1}$ (Invitrogen), seeded in 96-well microtitre plates at a density of $1 \times 10^{4}$ per well, and cultured to confluence. HMEC-1 cells were then stimulated with $10 \mu \mathrm{g} \mathrm{MspTL} \mathrm{ml}^{-1}$ in serum-free medium for $12 \mathrm{~h}$. MspTLstimulated THP-1 cells $\left(1 \times 10^{6}\right.$ cells per well $)$ were washed, resuspended in serum-free RPMI 1640 medium, and added to MspTL-stimulated HMEC-1 for 6, 12 and $24 \mathrm{~h}$ in a humidified atmosphere with $5 \% \mathrm{CO}_{2}$. Alternatively, non-stimulated THP-1 cells were added to MspTL-stimulated HMEC-1 cells or MspTL-stimulated THP-1 cells were added to non-stimulated HMEC-1 cells. After incubation, non-adherent THP-1 cells were carefully washed off with PBS. The remaining cells were fixed with absolute ethanol and left to dry. The cells were then stained with $0.1 \%$ methylene blue in $100 \mathrm{mM}$ borate buffer ( $\mathrm{pH} \mathrm{8.7)}$ for $10 \mathrm{~min}$ and washed with $10 \mathrm{mM}$ borate buffer three times. After adding $0.1 \mathrm{M} \mathrm{HCl}(100 \mu \mathrm{l}$ per well $)$ at $37{ }^{\circ} \mathrm{C}$ for $30 \mathrm{~min}$ to solubilize the dye bound by the cells, the $A_{650}$ was measured. All assays were performed in triplicate and the binding of non-stimulated THP-1 cells to non-stimulated HMEC-1 cells was used for basal cell adherence. The number of bacteria equivalent to $10 \mu \mathrm{g}$ of MspTL was approximately $5 \times 10^{8}$ cells (Lee et al., 2005).

Transendothelial migration assay. The ability of MspTL to induce monocyte transmigration across an endothelial cell monolayer was assessed using the Transwell plate system (Corning). HMEC-1 cells $\left(5 \times 10^{4}\right.$ cells per well) were seeded in the upper chamber of Transwell culture plates $(6.5 \mathrm{~mm}$ Transwell inserts with $8 \mu \mathrm{m}$ pore, Corning Costar) and cultured to confluence. Confluence of the monolayer was confirmed by microscopy. HMEC-1 cells were stimulated with $10 \mu \mathrm{g}$ MspTL $\mathrm{ml}^{-1}$ in serum-free MCDB131 medium for $24 \mathrm{~h}$, and in parallel, THP-1 cells were separately stimulated with $10 \mu \mathrm{g}$ MspTL $\mathrm{ml}^{-1}$ in serum-free RPMI 1640 medium for $24 \mathrm{~h}$. After changing the medium in the upper chamber, MspTL-stimulated THP-1 cells $\left(1 \times 10^{6}\right.$ cells per well $)$ were placed on top of the HMEC- 1 cells in the upper chamber and allowed to migrate through the HMEC-1 monolayer into the lower chamber at $37^{\circ} \mathrm{C}$ for $20 \mathrm{~h}$ in a humidified atmosphere with $5 \% \mathrm{CO}_{2}$. The migration assay was also performed using MspTL-stimulated THP-1 cells/non-stimulated HMEC-1 or non-stimulated THP-1 cells/MspTL-stimulated HMEC-1. The medium was taken from the lower chamber and migrated THP-1 cells were counted under a microscope using a cell-counting haemocytometer.

Treatment of host cells with MspTL polypeptides. We used THP-1 cells to assess the biological activities of MspTL polypeptides. THP-1 cells were cultured in RPMI 1640 with $10 \%$ FBS. The cells were seeded in $35 \mathrm{~mm}$ cell culture dishes at a density of $1 \times 10^{6} \mathrm{cells} \mathrm{ml}^{-1}$ and cultured overnight. After replacing the medium with serum-free medium, the cells were stimulated with $0.16 \mu \mathrm{M}$ of recombinant polypeptides for $12-24 \mathrm{~h}$. This concentration of polypeptides was equivalent to $10 \mu \mathrm{g} \mathrm{ml}^{-1}$ of MspTL, which we used in our previous study (Lee et al., 2005). The cells were harvested for RNA isolation and flow cytometry analysis, and the conditioned culture supernatants were

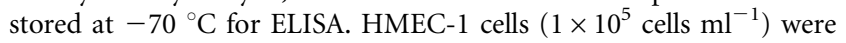
cultured in $35 \mathrm{~mm}$ cell culture dishes to confluence. After replacing the medium with the serum-free medium, the cells were stimulated with $10 \mu \mathrm{g}$ MspTL $\mathrm{ml}^{-1}$ for $12 \mathrm{~h}$ and analysed for ICAM-1 and IL-8 mRNA expression by RT-PCR as described below. Non-stimulated cells and cells stimulated with mock extracts were used as negative controls.

Expression of ICAM-1 by flow cytometry. THP-1 cells were stimulated with recombinant MspTL polypeptides for $24 \mathrm{~h}$ and the expression of ICAM-1 was evaluated by flow cytometry after reacting cells with anti-human ICAM-1 antibody and subsequently with FITClabelled IgG antibody as described previously (Lee et al., 2005).

RT-PCR and real-time RT-PCR. Total RNA was extracted from the cells stimulated with MspTL or polypeptides of MspTL using TRIzol reagent (Invitrogen). cDNA was synthesized by mixing RNA $(1 \mu \mathrm{g})$ and Maxime RT premix (iNtRON) in a $20 \mu \mathrm{l}$ reaction volume and incubating the mixture at $42{ }^{\circ} \mathrm{C}$ for $1 \mathrm{~h}$. RT-PCR was performed to analyse the expression of ICAM-1 and IL- 8 in HMEC- 1 by MspTL as described previously (Lee et al., 2005). For real-time RT-PCR, the cDNA $(1 \mu \mathrm{l})$ was mixed with $10 \mu \mathrm{l}$ SYBR Premix Ex Taq (Takara Bio) and primer pairs $(0.2 \mathrm{pmol}$ each) in a $20 \mu \mathrm{l}$ reaction volume, followed by PCR for 40 cycles with $95{ }^{\circ} \mathrm{C}$ denaturation for $15 \mathrm{~s}, 60{ }^{\circ} \mathrm{C}$ annealing for $15 \mathrm{~s}$ and $72{ }^{\circ} \mathrm{C}$ extension for $33 \mathrm{~s}$ in an ABI PRISM 7500 Fast Real-Time PCR System (Applied Biosystems). The PCR products were subjected to a melting curve analysis to verify a single amplification product. PCR without RT was performed as a negative control. The housekeeping gene encoding glyceraldehyde-3-phosphate dehydrogenase (GAPDH) was used as a reference in order to 
con MspTL

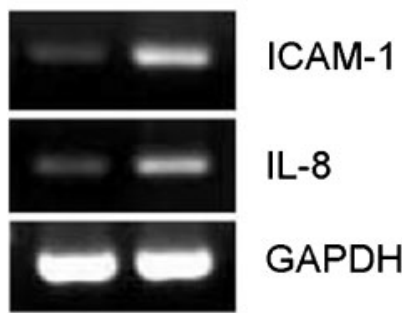

Fig. 1. Induction of ICAM-1 and IL-8 mRNA expression by MspTL in HMEC-1. HMEC-1 cells $\left(1 \times 10^{5}\right.$ cells $\left.\mathrm{ml}^{-1}\right)$ were cultured in $35 \mathrm{~mm}$ cell culture dishes to confluence. After the medium was replaced with serum-free medium, the cells were stimulated with MspTL $\left(10 \mu \mathrm{g} \mathrm{ml}^{-1}\right)$ for $12 \mathrm{~h}$. The total RNA was isolated from the cells, and ICAM-1 and IL- 8 mRNA expression was determined by RT-PCR. Non-stimulated cells (con) were used as a control.

normalize expression levels and quantify changes in gene expression between non-stimulated controls and MspTL polypeptide-stimulated cells. The expression fold change of each gene was determined from the difference in cycle numbers to reach a threshold value between control and MspTL-stimulated cells and was expressed in a $\log _{2}$ ratio. The genes analysed by real-time RT-PCR were ICAM-1, IL-1 $\beta$, IL-6, IL-8, tumour necrosis factor-alpha (TNF- $\alpha$ ) and cyclooxygenase (COX)-2. For the inhibition assay, the cells were pretreated with NS-398 (Sigma-Aldrich), a specific COX-2 inhibitor, for $30 \mathrm{~min}$ before treatment with MspTL polypeptides. The sequences of the primers for real-time RT-PCR were as follows: $5^{\prime}$-CATATGCCATGCAGCTACAC-3' and 5'-AGTTGTATGTCCTCATGGTG-3' for ICAM- 1 ; $5^{\prime}$-AGCTGTACCCAGAGAGTCC- ${ }^{\prime}$ and $5^{\prime}$-ACCAAATGTGGCCGTGGTTT- $3^{\prime}$ for IL- $1 \beta$; $5^{\prime}$-AACCTGTCCACTGGGCACA-3' and $5^{\prime}$-TCTGGCTCTGAAACAAAGGAT-3' for IL-6; 5'-GTGAAGGTGCAGTTTTGCCA- $3^{\prime}$ and $5^{\prime}$-TCTCCACAACCCTCTGCAC-3' for IL-8; 5'-CAGGGACCTCTCTCTAATCA-3' and $5^{\prime}$-AGCTGGTTATCTCTCAGCTC-3' for TNF- $\alpha$; $5^{\prime}$-AAGCTGGGAAGCCTTCTCTA-3' and 5'-GTGCTGGGCAAAGAATGCAA-3' for
COX-2; and 5'-GTGGTGGACCTGACCTGC-3' and 5'-TGAGCTTGACAAAGTGGTCG-3' for GAPDH.

ELISA. The culture supernatants of THP-1 cells stimulated with MspTL polypeptides were assayed to determine IL- 8 and $\mathrm{PGE}_{2}$ levels using ELISA kits from R\&D Systems.

Statistical analysis. The statistical significance of the differences between non-stimulated and MspTL polypeptide-stimulated cells or between MspTL polypeptide and MspTL polypeptide/inhibitortreated cells was evaluated using Student's $t$-test. A $P$ value of less than 0.05 was considered significant.

\section{RESULTS}

\section{Adhesion of monocytes on endothelial cells by MspTL}

In our previous study, MspTL significantly induced ICAM1 and IL-8 in THP-1 and PDL cells (Lee et al., 2005). ICAM-1 is a representative adhesion molecule for endothelial cells and IL-8 is a chemoattractant for various types of cells. In addition, both molecules contribute to cell adhesion and migration, and so we first analysed whether MspTL induced ICAM-1 and IL-8 in HMEC-1. As shown in Fig. 1, MspTL induced ICAM-1 and IL-8 mRNA expression. Next, we analysed the binding of monocytes to and transmigration through endothelial cell layers, using THP-1 and HMEC-1 cells. As shown in Fig. 2, MspTL significantly increased the binding of THP-1 cells to endothelial cells. The binding capacity was higher in experiments using both cell types stimulated with MspTL than in those where only one type of cell was stimulated with MspTL and the other was not stimulated.

To assess the transmigration, a chemotactic gradient was created through the endothelial cells by changing the

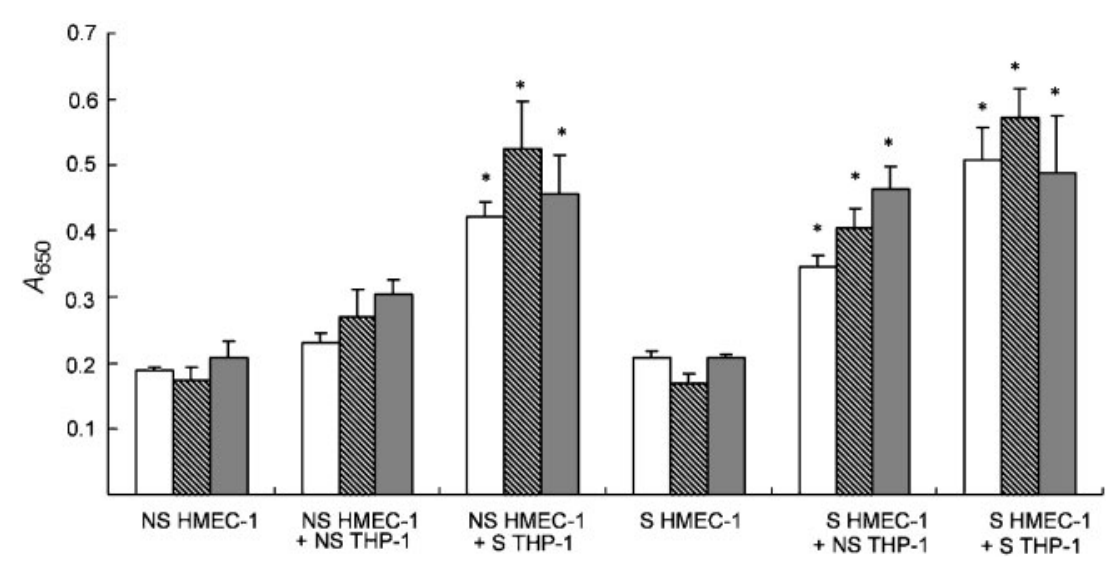

Fig. 2. Increased monocyte binding to HMEC-1 stimulated by MspTL. HMEC-1 cells were cultured to confluence and stimulated with MspTL $\left(10 \mu \mathrm{g} \mathrm{ml}^{-1}\right)$ for $12 \mathrm{~h}$. THP-1 cells stimulated with MspTL $\left(10 \mu \mathrm{g} \mathrm{ml}^{-1}\right)$ for $12 \mathrm{~h}$ were placed on the HMEC-1 and allowed to bind for 6 (white), 12 (hatched) and $24 \mathrm{~h}$ (grey) at $37^{\circ} \mathrm{C}$. Non-adherent monocytes were washed off and the remaining total cells were fixed with ethanol and stained with $0.1 \%$ methylene blue. After washing the unbound dye, the stained methylene blue was released using $0.1 \mathrm{M} \mathrm{HCl}$ and $A_{650}$ was measured. The value of the binding of non-stimulated THP-1 cells to non-stimulated HMEC-1 represents the basal binding. NS, nonstimulated; S, stimulated with MspTL; *, statistically significant $(P<0.05)$ differences in cell adhesion compared to control values using non-stimulated THP-1 cells and HMEC-1. 
medium of HMEC-1 stimulated with MspTL only in the upper chamber before adding THP-1 cells. MspTL significantly increased transendothelial migration of THP-1 cells compared to non-stimulated control cells $(P<0.05)$. The migrated cell number was significantly greater in the combination of stimulated HMEC-1 and non-stimulated THP-1 cells $(30975 \pm 6682$ cells, mean \pm SD) than in the combination of non-stimulated HMEC- 1 and stimulated THP-1 cells $(16725 \pm 106$ cells), because of a chemotactic gradient in the former case. The migrated cell number was highest in experiments using both cell types stimulated with MspTL ( $39450 \pm 7990$ cells), while the control value using non-stimulated THP-1 cells and HMEC- 1 was $14525 \pm 742$ cells.

\section{Expression of partial MspTL polypeptides}

Truncated recombinant MspTL polypeptides were produced to determine the functional regions of MspTL with regard to host cell stimulation. MspTL and its partial polypeptides were successfully expressed in $E$. coli and the recombinant proteins were detected at the position of the predicted molecular masses when analysed by SDS-PAGE (Fig. 3).

(a)

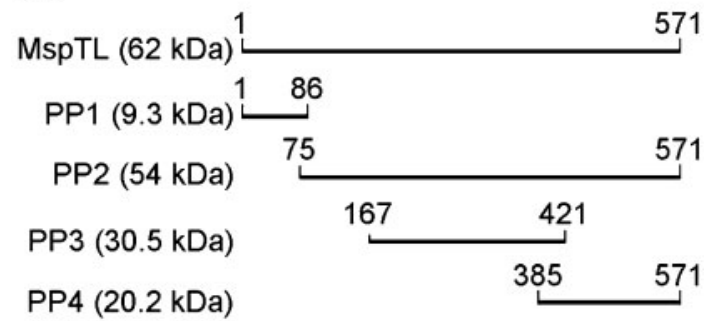

(b)

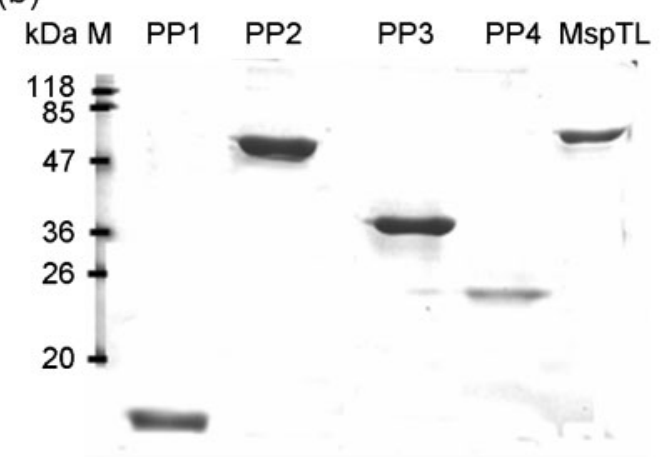

Fig. 3. Construction of truncated MspTL polypeptides and their expression in E. coli. (a) Position of the partial polypeptides in MspTL and (b) recombinant polypeptides purified after cloning in E. coli using the expression vector pQE-30. MspTL has 571 amino acids without the signal peptide. The amino acid positions are indicated in each polypeptide. Molecular masses of the peptides are indicated in parentheses.

\section{Induction of ICAM-1 and IL-8 by MspTL polypeptides}

To determine which fragments of MspTL promoted the biological activities, we analysed the ability of the truncated recombinant polypeptides to induce ICAM- 1 and IL- 8 in THP-1 cells. As shown in Fig. 4(a), PP1, 2 and 3 significantly induced mRNA expression of these factors in THP-1 cells as demonstrated by real-time RT-PCR. Among the polypeptides, PP1, which encompasses the first 86 amino acids of MspTL, induced ICAM-1 and IL-8 expression most significantly. PP4 exhibited minimal stimulating activity. To determine the induction at the protein level, we evaluated ICAM-1 expression by flow cytometry and IL-8 level by ELISA. As shown in Fig. 4(b), PP1 induced ICAM-1 and IL-8 expression most significantly and the level was equivalent to or higher than that of MspTL-induced cells. The dose-dependent induction of ICAM-1 expression by PP1 is shown in Fig. 4(c).

\section{Induction of proinflammatory factors by PP1}

Since PP1 was the most potent inducer for ICAM-1 and IL-8, we further analysed its ability to modulate other inflammatory factors. As shown in Fig. 5, PP1 significantly upregulated mRNA of IL- $1 \beta$, TNF- $\alpha$, IL- 6 and COX-2 in THP-1 cells.

\section{Induction of $\mathrm{PGE}_{\mathbf{2}}$ by PP1}

$\mathrm{PGE}_{2}$ is an important inflammatory factor. Since MspTL and PP1 induced COX-2 mRNA expression, we tested for their ability to induce $\mathrm{PGE}_{2}$, a COX-2 product. As shown in Fig. 6, MspTL and PP1 significantly induced $\mathrm{PGE}_{2}$ in THP-1 cells. PGE $_{2}$ levels were reduced to control levels when the cells were pretreated with NS-398, a specific COX-2 inhibitor, before treatment with MspTL or PP1.

\section{DISCUSSION}

Information about biologically active sites of bacterial surface proteins is important for understanding pathogenesis and will help to deduce conserved sequences and structural elements that can be used to develop eradication strategies. In our previous study, we showed that $T$. lecithinolyticum major surface protein, MspTL, stimulated proinflammatory mediators including ICAM-1, IL- $1 \beta$, IL-6 and IL-8 in host cell types such as monocytes and fibroblasts (Lee et al., 2005). In additional experiments, we observed that MspTL-induced ICAM-1 expression accounted for more than $80 \%$ of that induced by the equivalent amounts of $T$. lecithinolyticum whole cells or lysates. Therefore, we assume that MspTL is a main player of host cell stimulation with respect to ICAM-1 induction. In this study, we further characterized MspTL with regard to its role in monocyte adhesion and transepithelial migration, and determined the proinflammatory regions using truncated recombinant MspTL polypeptides. 
(a)

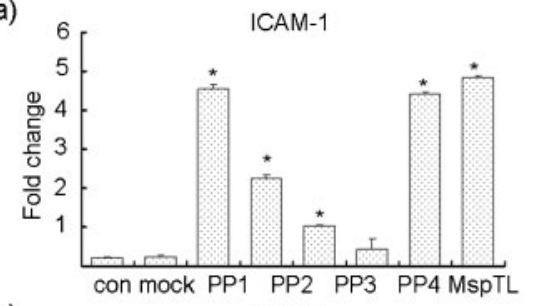

(b)

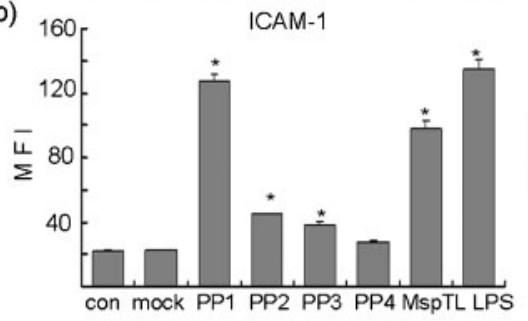

(c)

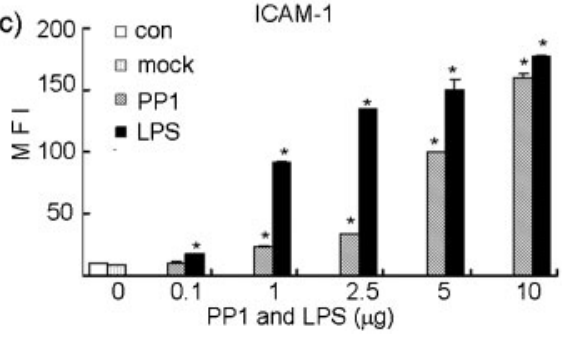

IL-8

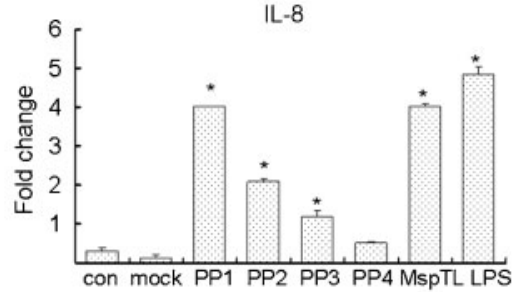

IL-8

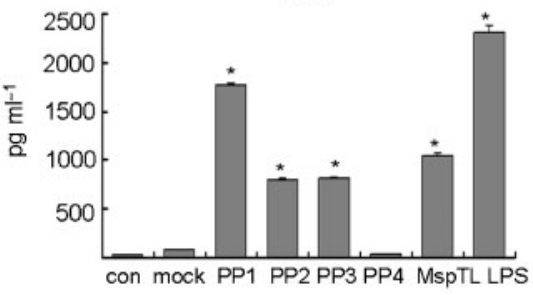

Fig. 4. Induction of ICAM- 1 and $I L-8$ by MspTL and its partial polypeptides. THP-1 cells $\left(1 \times 10^{6} \mathrm{cell} \mathrm{ml}^{-1}\right)$ were seeded in $35 \mathrm{~mm}$ cell culture dishes and cultured overnight. (a) After replacing the medium with serum-free medium, the cells were stimulated with $0.16 \mu \mathrm{M}$ MspTL (equivalent to $10 \mu \mathrm{g} \mathrm{ml}^{-1}$ ) or each recombinant polypeptide for 12-24 h. RNA was isolated from the cells (12-hstimulated cells) and real-time RT-PCR was performed for ICAM-1 and IL-8 mRNA expression. (b) The cells (24-h-stimulated) were subjected to flow cytometry analysis for ICAM-1 expression, and the conditioned media were analysed for IL-8 level by ELISA. LPS $\left(10 \mu \mathrm{g} \mathrm{ml}^{-1}\right)$ was used as a positive control. (c) Dose-dependent induction of ICAM-1 expression in THP-1 cells by PP1 and LPS. ${ }^{*}$, significant differences $(P<0.05)$ compared with the non-stimulated controls; $\mathrm{MFI}$, mean fluorescence intensity.

The interaction between monocytes and the endothelium is a key process in many inflammatory diseases, including periodontitis. Since MspTL induced IL-8, a classical chemokine, and ICAM-1, an adhesion molecule, in both monocytes and endothelial cells, we examined monocyteendothelial cells interaction. MspTL induced monocyte adhesion to endothelial cells and transendothelial migration. These results suggest that MspTL may play an important role in the initial infiltration of monocytes into the periodontal tissues in periodontitis. Fimbriae of Porphyromonas gingivalis, a periodontal pathogen with strong proteolytic activities, have been reported to induce human monocyte adhesion to endothelial cells through the interaction between CD11b/CD18 and ICAM-1 (Harokopakis et al., 2006), depending on Toll-like receptor 2, Racl and phosphatidylinositol 3-kinase.

To identify regions critical to MspTL function we designed partial polypeptides of MspTL and evaluated their ability to induce inflammatory host factors. The N-terminal region of MspTL (86 amino acids) exerted a biological activity equivalent to the whole protein in terms of inducing proinflammatory mediators like IL- $1 \beta$, TNF- $\alpha$, IL-6, IL-8 and $\mathrm{PGE}_{2}$. Prediction of protein subcellular localization analysed using the program PSORTb (Gardy et al., 2005) resulted in the localization of MspTL in the outer
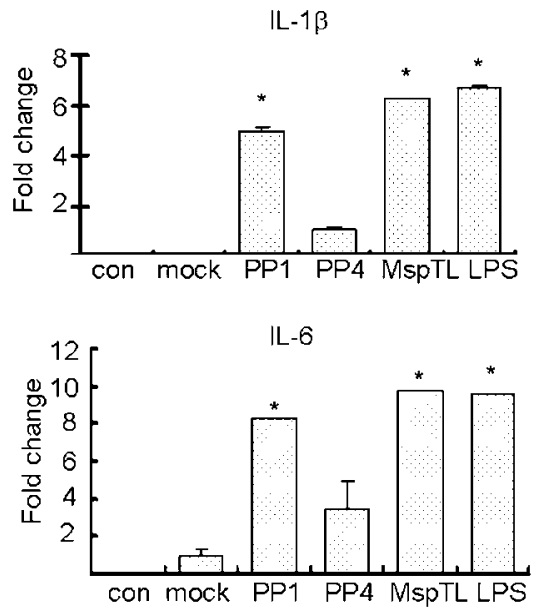
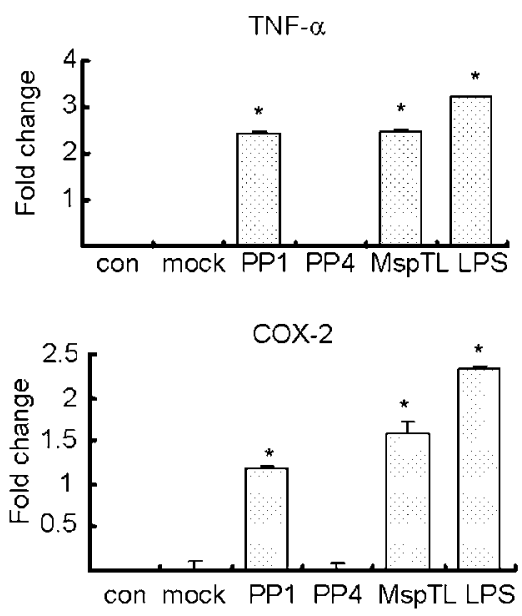

Fig. 5. Induction of proinflammatory factors in THP-1 cells by MspTL and PP1. THP-1 cells were cultured and stimulated with MspTL or PP1 for $12 \mathrm{~h}$ as described in Fig. 4, and analysed by real-time RT-PCR. LPS $(10 \mu \mathrm{g}$ $\mathrm{ml}^{-1}$ ) was used as a positive control and PP4 as a negative control. *, significant differences $(P<0.05)$ compared with the non-stimulated controls. 


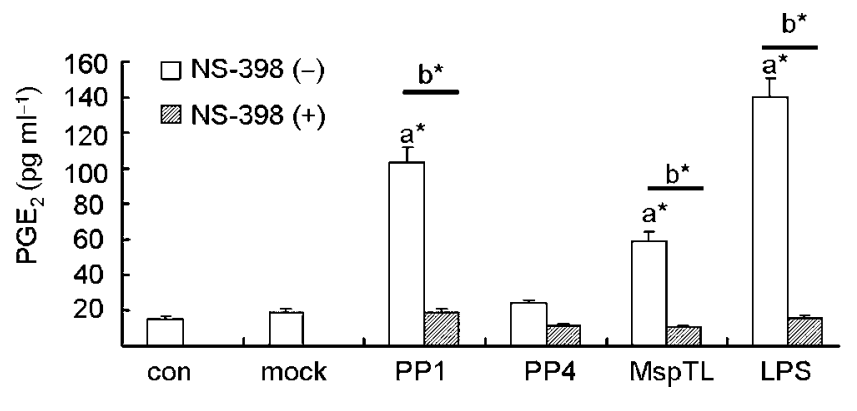

Fig. 6. Induction of $P G E_{2}$ in THP-1 cells by MspTL and PP1. THP-1 cells were cultured and stimulated with MspTL or PP1 as described in Fig. 4. For the inhibition assay, the cells were pretreated with NS-398 for 30 min before treatment with MspTL and PP1. PGE 2 levels in the conditioned media were measured by ELISA. LPS $\left(10 \mu \mathrm{g} \mathrm{ml}^{-1}\right)$ was used as a positive control and PP4 as a negative control. ${ }^{*}$, significant differences $(P<0.05)$; a, stimulated cells compared with the non-stimulated controls; b, stimulated cells compared with inhibitor-treated cells.

membrane with a likelihood of $94.9 \%$. Predicted secondary structure of MspTL using the programs PSIPRED (Jones, 1999) and DSSP (Kabsch \& Sander, 1983) revealed that most of the protein is composed of $\beta$-strands and loop regions. The N-terminal 86 amino acids of MspTL form the structure of three $\beta$-sheet membrane-spanning segments with two surface-exposed loops and two periplasmic short segments, when analysed with the program PRED-TMBB (Bagos et al., 2005) predicting the topology of $\beta$-barrel outer-membrane proteins. Therefore, the $\mathrm{N}$ terminus could be thought to come into contact with the host cells via the surface-exposed loops.

The major surface protein, $53 \mathrm{kDa}$ Msp, of Treponema denticola, the most intensively studied oral treponeme, is well characterized and regarded as an important virulence factor. It is an adhesin that binds to host cells and various tissue proteins such as fibronectin, keratin, laminin, collagen, fibrinogen, hyaluronic acid and heparin (Edwards et al., 2005). Msp causes cytopathic effects, forming ion channels within lipid bilayers of epithelial cells and disrupting calcium signalling in fibroblasts (Fenno et al., 1998; Wang et al., 2001). It also triggers release of MMP-8, MMP-9, cathepsin G and elastase from neutrophils (Ding et al., 1996), suggesting its role in periodontal tissue destruction. Recently, using recombinant partial polypeptides of Msp and region-specific antibodies, Edwards et al. (2005) analysed epitopes involved in mediating adhesion and found that the $\mathrm{N}$-terminal half of Msp, particularly the central variable sequence region, carries this function. Although MspTL of T. lecithinolyticum and Msp of T. denticola are not homologous proteins, they are among the most abundant proteins in these bacteria. Therefore, accumulating data on the functional motifs of such proteins in oral spirochaetes will provide ideas about what controls the pathogenesis of the bacteria.
Various inflammatory mediators are synthesized in response to periodontal pathogens and their products and contribute to the initiation and progression of periodontitis, ultimately leading to periodontal tissue destruction, including alveolar bone resorption. High levels of inflammatory mediators are detected in gingival crevicular fluid (GCF) and periodontal tissues of periodontitis patients compared to periodontally healthy individuals (Gorska et al., 2003; Sakai et al., 2006; Wang et al., 2003). The presence of IL- $1 \beta$, IL- 6 , TNF- $\alpha$ and $\mathrm{PGE}_{2}$ in GCF is correlated with clinical signs of periodontitis such as a significantly higher plaque index and gingival index, deeper pocket probing depth and greater loss of attachment (Champagne et al., 2003). These factors are also potent bone-resorbing mediators that induce alveolar bone resorption, leading to tooth loss. Previously, we observed that $T$. lecithinolyticum lysates induced osteoclastogenesis in a co-culture system composed of mouse bone marrow cells and calvaria-derived osteoblastic cells, and that this process was dependent on $\mathrm{PGE}_{2}$ (Choi et al., 2001b). MspTL may be the main player behind the increase of $\mathrm{PGE}_{2}$ by T. lecithinolyticum.

In summary, we have demonstrated the ability of MspTL to induce the expression of proinflammatory mediators involved in cell adhesion, inflammation and bone resorption. The N-terminal polypeptide of 86 aa was critical to the stimulation of host cells and the pathological effect of MspTL. We are further pursuing a fine map of the Nterminal region that will contribute to the identification of potential targets to prevent pathogenesis of the major surface protein of T. lecithinolyticum.

\section{ACKNOWLEDGEMENTS}

This work was supported by the Korea Research Foundation Grant funded by the Korean Government (MOEHRD, Basic Research Promotion Fund) (KRF-2006-531-E00072). H.-K. J., H.-R. L. and S.-H.L. are recipients of a scholarship from BK21 program (Craniomaxillofacial Life Science 21).

\section{REFERENCES}

Al-Numani, D., Segura, M., Dore, M. \& Gottschalk, M. (2003). Upregulation of ICAM-1, CD11a/CD18 and CD11c/CD18 on human THP-1 monocytes stimulated by Streptococcus suis serotype 2. Clin Exp Immunol 133, 67-77.

Bagos, P. G., Liakopoulos, Th. D. \& Hamodrakas, S. J. (2005). Evaluation of methods for predicting the topology of $\beta$-barrel outer membrane proteins and a consensus prediction method. BMC Bioinformatics 6, 7 .

Champagne, C. M., Buchanan, W., Reddy, M. S., Preisser, J. S., Beck, J. D. \& Offenbacher, S. (2003). Potential for gingival crevice fluid measures as predictors of risk for periodontal diseases. Periodontol 2000 31, 167-180.

Choi, B. K., Paster, B. J., Dewhirst, F. E. \& Gobel, U. B. (1994). Diversity of cultivable and uncultivable oral spirochetes from a patient with severe destructive periodontitis. Infect Immun 62, 1889-1895. 
Choi, B. K., Jung, J. H., Suh, H. Y., Yoo, Y. J., Cho, K. S., Chai, J. K. \& Kim, C. K. (2001a). Activation of matrix metalloproteinase-2 by a novel oral spirochetal species Treponema lecithinolyticum. J Periodontol 72, 1594-1600.

Choi, B. K., Ohk, S. H., Lee, H. J., Kang, J. H., Jeong, G. J. \& Yoo, Y. J. (2001b). Effects of whole cell sonicates of Treponema lecithinolyticum on osteoclast differentiation. J Periodontol 72, 1172-1177.

Correia, F. F., Plummer, A. R., Ellen, R. P., Wyss, C., Boches, S. K., Galvin, J. L., Paster, B. J. \& Dewhirst, F. E. (2003). Two paralogous families of a two-gene subtilisin operon are widely distributed in oral treponemes. J Bacteriol 185, 6860-6869.

Dewhirst, F. E., Tamer, M. A., Ericson, R. E., Lau, C. N., Levanos, V. A., Boches, S. K., Galvin, J. L. \& Paster, B. J. (2000). The diversity of periodontal spirochetes by $16 \mathrm{~S}$ rRNA analysis. Oral Microbiol Immunol 15, 196-202.

Ding, Y., Uitto, V. J., Haapasalo, M., Lounatmaa, K., Konttinen, Y. T., Salo, T., Grenier, D. \& Sorsa, T. (1996). Membrane components of Treponema denticola trigger proteinase release from human polymorphonuclear leukocytes. J Dent Res 75, 1986-1993.

Edwards, A. M., Jenkinson, H. F., Woodward, M. J. \& Dymock, D. (2005). Binding properties and adhesion-mediating regions of the major sheath protein of Treponema denticola ATCC 35405. Infect Immun 73, 2891-2898.

Fenno, J. C., Hannam, P. M., Leung, W. K., Tamura, M., Uitto, V. J. \& McBride, B. C. (1998). Cytopathic effects of the major surface protein and the chymotrypsinlike protease of Treponema denticola. Infect Immun 66, 1869-1877.

Gardy, J. L., Laird, M. R., Chen, F., Rey, S., Walsh, C. J., Ester, M. \& Brinkman, F. S. L. (2005). PSORTb v.2.0: expanded prediction of bacterial protein subcellular localization and insights gained from comparative proteome analysis. Bioinformatics 21, 617-623.

Gorska, R., Gregorek, H., Kowalski, J., Laskus-Perendyk, A., Syczewska, M. \& Madalinski, K. (2003). Relationship between clinical parameters and cytokine profiles in inflamed gingival tissue and serum samples from patients with chronic periodontitis. J Clin Periodontol 30, 1046-1052.
Harokopakis, E., Albzreh, M. H., Martin, M. H. \& Hajishengallis, G. (2006). TLR2 transmodulates monocyte adhesion and transmigration via Rac1- and PI3K-mediated inside-out signaling in response to Porphyromonas gingivalis fimbriae. J Immunol 176, 7645-7656.

Jones, D. T. (1999). Protein secondary structure prediction based on position-specific scoring matrices. J Mol Biol 292, 195-202.

Kabsch, W. \& Sander, C. (1983). Dictionary of protein secondary structure: pattern recognition of hydrogen-bonded and geometrical features. Biopolymers 22, 2577-2637.

Lee, S. H., Kim, K. K. \& Choi, B. K. (2005). Upregulation of intercellular adhesion molecule 1 and proinflammatory cytokines by the major surface proteins of Treponema maltophilum and Treponema lecithinolyticum, the phylogenetic group IV oral spirochetes associated with periodontitis and endodontic infections. Infect Immun 73, 268-276.

Moter, A., Riep, B., Haban, V., Heuner, K., Siebert, G., Berning, M., Wyss, C., Ehmke, B., Flemmig, T. F. \& Gobel, U. B. (2006). Molecular epidemiology of oral treponemes in patients with periodontitis and in periodontitis-resistant subjects. J Clin Microbiol 44, 3078-3085.

Sakai, A., Ohshima, M., Sugano, N., Otsuka, K. \& Ito, K. (2006). Profiling the cytokines in gingival crevicular fluid using a cytokine antibody array. J Periodontol 77, 856-864.

Wang, Q., Ko, K. S., Kapus, A., McCulloch, C. A. \& Ellen, R. P. (2001). A spirochete surface protein uncouples store-operated calcium channels in fibroblasts: a novel cytotoxic mechanism. J Biol Chem 276, 23056-23064.

Wang, P. L., Ohura, K., Fujii, T., Oido-Mori, M., Kowashi, Y., Kikuchi, M., Suetsugu, Y. \& Tanaka, J. (2003). DNA microarray analysis of human gingival fibroblasts from healthy and inflammatory gingival tissues. Biochem Biophys Res Commun 305, 970-973.

Wyss, C., Choi, B. K., Schupbach, P., Moter, A., Guggenheim, B. \& Gobel, U. B. (1999). Treponema lecithinolyticum sp. nov., a small saccharolytic spirochaete with phospholipase A and C activities associated with periodontal diseases. Int J Syst Bacteriol 49, 1329-1339.

Edited by: M. A. Curtis 